\title{
Biofilm forming ability of Salmonella enterica serovar Tennessee isolates originating from feed
}

\author{
Dubravka Milanov*, Bojana Prunić, Dragana Ljubojević \\ Scientific Veterinary Institute „Novi Sad“, Novi Sad, Serbia
}

\begin{abstract}
MILANOV, D., B. PRUNIĆ, D. LJUBOJEVIĆ: Biofilm forming ability of Salmonella enterica serovar Tennessee isolates originating from feed. Vet. arhiv 87, 691-702, 2017.
\end{abstract}

\section{ABSTRACT}

Salmonella enterica subspecies enterica serovar Tennessee was the most frequent Salmonella serovar isolated from plant-based animal feed throughout a two-year period (2012-2013) of research conducted in the region of the Autonomous Province of Vojvodina. In this study, the ability of biofilm formation was investigated on 20 isolates of $S$. Tennessee. The starting point for this research was the established biofilm-forming ability of serovar Tennessee strains, which significantly contributes to their wide distribution in the environment (plant materials), and hence in animal feed. In this study, biofilm formation was investigated on polystyrene (microplate biofilm assay) and stainless steel (scanning electron microscopy) surfaces by culturing in Luria Bertani broth (LB) and Triptone Soya Broth (TSB). The expression of major matrix components of Salmonella biofilm (curli fimbriae and cellulose) was examined by cultivation on Congo Red agar. All isolates of $S$. Tennessee produced a biofilm on a polystyrene surface in a microtiter plate test, by cultivation in LB at an incubation temperature of $20^{\circ} \mathrm{C}$. Scanning electron microscopy revealed biofilm formation of $S$. Tennessee on a stainless steel surface by cultivation in LB, but not in TSB. The expression of curli fimbriae and cellulose, as well as the formation of characteristic "rdar" colonies on Congo Red agar has been observed in all isolates of $S$. Tennessee. This serovar is not specifically adapted to humans and animals, so the available epidemiological data do not indicate its major implication in food-borne infection outbreaks. However, this serovar manifests a pronounced ability for adherence to plant surfaces, biofilm formation and increased resistance to long-term desiccation, which is the most likely explanation for its frequent identification in low water activity feed.

Key words: Salmonella Tennessee, biofilm, feed

\section{Introduction}

Non-typhoid serotypes of Salmonella enterica (NTS) are considered to be the most important human and animal foodborne pathogens worldwide, from both economic and

\footnotetext{
*Corresponding author:

Dubravka Milanov, PhD., DVM, Senior Research Associate, Scientific Veterinary Institute „Novi Sad“, Rumenački put 20 , 21000 Novi Sad, Serbia, Phone: +381 214895 346; Fax: +381 21518 544; E-mail: dubravka@niv.ns.ac.rs
} 
health aspect. The routes of entry of NTS into food and animal feed are numerous, at all production stages from farm to fork (PATEL and SHARMA, 2010; WHO, 2013). Raw materials of plant origin are the most common source of NTS in feed. Salmonella spp. can enter plant material via contaminated irrigation water or raw manure. The prominent feature of Salmonella organisms is their ability not only to contaminate but actively to colonize and invade plants, which has recently been confirmed using microscopy techniques for in situ visualization (LAPIDOT and YARON, 2009; KROUPITSKI et al., 2009; PATEL and SHARMA, 2010). Salmonella are introduced into the feed factories via contaminated raw material (NESSE et al., 2003). The organisms use similar survival strategies in both their natural habitat (plant surfaces) and the feed factory environment. After initial attachment to biotic and abiotic surfaces, salmonellas create multicellular communities, commonly referred to as biofilm. The biofilm organization pattern of salmonellas is most likely responsible for their increased resistance to a range of stress factors, such as long-term desiccation, low nutrients, and disinfectants from feed and the food factory environment (MØRETRØ et al., 2009; AVILES et al., 2013). Such multicellular behavior (biofilm) enables salmonellas to persist in the feed factory environment for months, even years (NESSE et al., 2003; VESTBY et al., 2009; MØRETRØ et al., 2009). Salmonella biofilms from equipment and food contact surfaces are a well-established source of long-lasting contamination of final products, which has been repeatedly confirmed by molecular methods (NESSE et al., 2003; PAPADOPOULOU et al., 2009).

In Great Britain, $S$. Tennessee is one of the top five most isolated serovars from feed for cattle, pigs and poultry (PAPADOPOULOU et al., 2009). Very frequent instances of isolation of this serovar from feed and feed ingredients have also been reported in Denmark (CHRISTENSEN et al., 1997). The starting point for this research was the premise of the crucial role of biofilm formation in the survival of $S$. Tennessee in the natural environment, and its frequent isolation from animal feeds in our epizootical area, the Autonomous Province of Vojvodina. In this study, we examined the ability for biofilm formation in 20 isolates of Salmonella Tennessee, applying common methods for investigation of the multicellular behavior of Salmonella: the microtiter-plate biofilm assay, the Congo Red agar test and scanning electron microscopy.

\section{Materials and methods}

Bacterial isolation, identification and storage. Throughout the two-year research period (2012-2013), the laboratory of the Scientific Veterinary Institute "Novi Sad" examined 2,898 animal feed samples and isolated 152 Salmonella spp. (5.25\%). Isolation and biochemical identification of Salmonella spp. was performed according to the guidelines of the EN ISO 6579:2008 standard (ISO 2008). The serotyping of the isolates was performed in the National Reference Laboratory for Salmonella, Shigella, Vibrio 
cholerae and Yersinia enterocolitica, of the Institute of Public Health of Serbia, Belgrade. The top five serovars identified included $S$. Tennessee (20\%), S. Montevideo (15\%), $S$. Enteritidis (14\%), S. Infantis (12\%) and S. Agona (9\%).

Biofilm production was examined using 20 selected strains of $S$. Tennessee originating from different feed factories. The strains were isolated from feed for cattle $(n=5)$, pigs $(n=6)$, poultry $(n=7)$ and soybean meal $(n=2)$. Until testing, the strains were stored in Tryptone Soya Broth (TSB) (CM0129, Oxoid, Basingstoke, UK) with 15\% glycerol, at $-70{ }^{\circ} \mathrm{C}$. Overnight cultures cultivated at $37{ }^{\circ} \mathrm{C}$ on Xylose Lysine Desoxycholate agar (XLD, Biokar diagnostics, Bequvais, Cedex-France) were used for the examination.

Congo Red agar test. Congo Red agar (CRA) was prepared using Luria Bertani broth (LB) without salt: Bacto Yeast Extract (5 g/L), Bacto Tryptone (10 g/L) (Becton, Dickinson and Company, Sparks, USA) with the addition of $40 \mathrm{mg} / \mathrm{L}$ Congo Red (MP Biomedicals, LCC, France) and $20 \mathrm{mg} / \mathrm{L}$ Comassie brilliant blue (Sigma-Aldrich Company Ltd. Dorset, England). All isolates were inoculated on CRA by the spot inoculation technique (single point). The testings were performed in duplicate, without repeating and sub-passaging of isolates. The plates were incubated for five days at $20{ }^{\circ} \mathrm{C}$ and $37^{\circ} \mathrm{C}$. The interpretation of the results was based on colonial morphotype as following: rdar (ㅁed, dry, and rough; expresses curli and cellulose), pdar (pink, dry, and rough; expresses cellulose), bdar

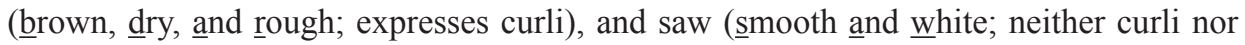
cellulose) (RÖMLING, 2005). A reference culture of $S$. Typhimurium ATCC 14028 was used as the positive control.

Microplate biofilm assay. Two distinct colonies of each isolate of $S$. Tennessee, grown over $24 \mathrm{~h}$ on XLD agar, were inoculated in $5 \mathrm{~mL}$ Buffered peptone water (BPW, CM1049, Oxoid, Basingstoke, UK) and multiplied at $37{ }^{\circ} \mathrm{C}$ for $18 \mathrm{~h}$. On the following day, the suspensions were diluted in fresh Tryptone Soya Broth and Luria Bertani broth at the ratio of 1:40, and $150 \mu \mathrm{L}$ aliquots of each isolate were added into 4 wells of sterile flat-bottom microtiter plates (Nunc, Rosklide, Denmark). Negative controls were placed on all microplates, 4 wells with $150 \mu \mathrm{L}$ aliquots of each one of TSB and LB. The plates were incubated for $48 \mathrm{~h}$ at $20^{\circ} \mathrm{C}$ and $37^{\circ} \mathrm{C}$. After incubation, the plates were washed three times with sterile saline $(250 \mu \mathrm{L}$ per each well) and allowed to dry at room temperature in an inverted position. Bacteria were fixed and inactivated with methanol $(250 \mu \mathrm{L}$ per well) for 20 minutes at room temperature. The biofilm staining was performed using $0.3 \%$ Crystal Violet aqueous solution (Sigma-Aldrich Company Ltd. Dorset, England), $200 \mu \mathrm{L}$ per well, during 15 minutes at room temperature. The plates were washed out under running water until there were no visible traces of color. Biofilmbound dye was then dissolved with $95 \%$ ethanol $(250 \mu \mathrm{L}$ per well) for 15 minutes. The test was performed twice. Optical density (OD) was measured spectrophotometrically (Labsystems Multiscan ${ }^{\circledR}$ MCC/340) using 595nm filter. Cut-off OD (ODc) was defined 
as three standard deviations above the mean OD of the negative control. Strains were classified as follows: non-biofilm producers $(\mathrm{OD} \leq \mathrm{ODc}$ ); weak biofilm producers (ODc $<\mathrm{OD} \leq 2 \times \mathrm{ODc})$; moderate biofilm producers $(2 \times \mathrm{ODc}<\mathrm{OD} \leq 4 \times \mathrm{ODc})$ and strong biofilm producers (OD $>4$ x ODc) (STEPANOVIĆ et al., 2003).

Statistical analysis. All data are shown as means and the corresponding standard deviation. The experimental design for the study was factorial, with 2 factors. The effects of the two factors and their interactions were analysed by two-way ANOVA (Statistica Version 10.0; StatSoft Inc., Tulsa, OK). Analysis of the simple main effects was performed for both factors. Differences were regarded as significant when $\mathrm{P}<0.05$

Scanning electron microscopy. Preparation for scanning electron microscopy was done using a selected isolate of $S$. Tennessee, a moderate biofilm producer according to the results obtained in the microtiter plate test. Suspensions of the selected isolate were prepared in LB and TSB according to the same protocol described for the microplate test. Bacterial suspension aliquots of $100 \mu \mathrm{L}$ were inoculated onto stainless steel coupons $(1 \mathrm{~cm} \times 1 \mathrm{~cm} \times 1 \mathrm{~mm})$. The coupons were placed into the wells of the Nunc polystyrene plate (12 well) (Roskilde, Denmark) and incubated for 4 days at $20^{\circ} \mathrm{C}$. After 48 hours, $100 \mu \mathrm{L}$-aliquots of fresh media (LB or TSB) were reapplied onto the coupon surface. Following 4-day incubation, the coupons were washed several times with sterile saline to remove unbound bacteria and medium residues. The coupons were fixed by submerging in $4 \%$ formaldehyde overnight in a refrigerator. Further dehydration was performed by submerging into serial dilutions of $30 \%, 50 \%, 70 \%$ and $95-96$ vol\% ethanol for $10 \mathrm{~min}$ each, and subsequent air-drying. The coupons were then sputter-coated with gold (Sputter Coater SCD 005, BALTEC SCAN, WD $=50 \mathrm{~mm}, 90 \mathrm{~s}, 30 \mathrm{~mA}$ ) and examined using a scanning electron microscope (JMS SEM 6460 LV).

\section{Results}

Congo Red agar test. All $S$. Tennessee isolates (Fig. 1. a., b.) as well as control strain $S$. Typhimurium ATCC 14028 (Fig. 1. c) produced a rdar colony morphotype on CRA after 5-day incubation at $20^{\circ} \mathrm{C}$. By incubation in CRA at $37^{\circ} \mathrm{C}$, all isolates produced a saw morphotype (Fig. 1.d). 
D. Milanov et al.: Biofilm forming ability of Salmonella ser. Tennessee isolated from feed
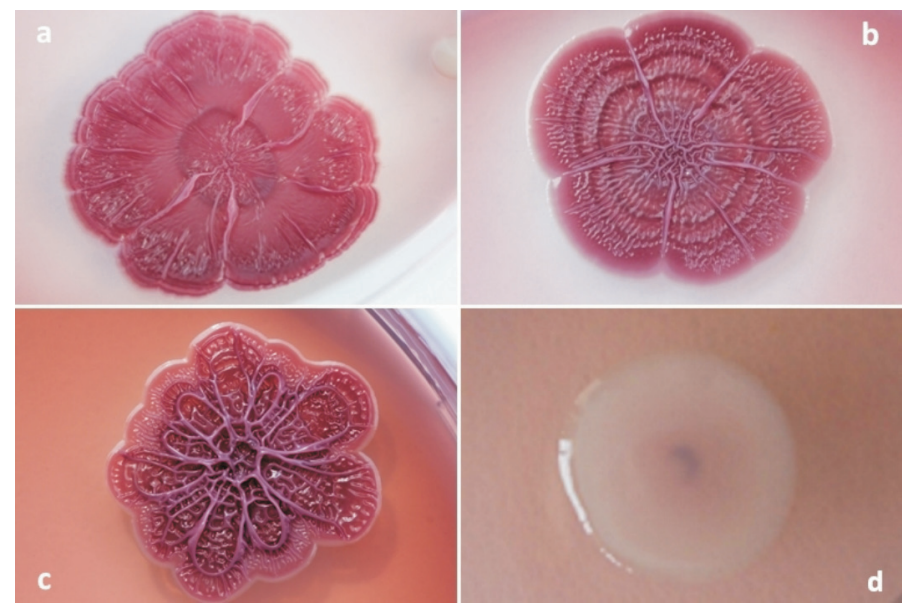

Fig. 1. Colony morphotypes on Congo Red agar: rdar morphotype of isolates $S$. Tennessee $(\mathrm{a}, \mathrm{b})$ and $S$. Typhimurium ATCC 14028 (c), incubation temperature $20^{\circ} \mathrm{C}$; saw morphotype of isolate $S$. Tennessee (d), incubation temperature $37^{\circ} \mathrm{C}$.

Microplate biofilm assay. The results of the microplate biofilm assay are presented in Table 1. According to the measured values for optical density and relevant calculations, cultivation in $\mathrm{LB}$ at $20{ }^{\circ} \mathrm{C}$ proved the most favorable environment for biofilm formation $(\mathrm{P}<0.05)$. The increase of the incubation temperature to $37^{\circ} \mathrm{C}$, as well as cultivation in reach nutritive medium (TSB), negatively affected the biofilm formation.

Table 1. Results of the microplate biofilm assay

\begin{tabular}{|l|c|c|c|c|c|c|}
\hline \multirow{2}{*}{ Broth } & \multicolumn{4}{|c|}{ Biofilm producer No. (\%) } & \multirow{2}{*}{} \\
\cline { 3 - 7 } & Temperature & Strong & Moderate & Weak & Non & Mean OD \pm SD \\
\hline \multirow{2}{*}{ Luria Bertani } & $20^{\circ} \mathrm{C}$ & 0 & $14(70)$ & $6(30)$ & 0 & $0.54 \pm 0.16^{\mathrm{a}}$ \\
\cline { 2 - 7 } & $37^{\circ} \mathrm{C}$ & 0 & $4(20)$ & $13(65)$ & $3(15)$ & $0.32 \pm 0.14^{\mathrm{b}}$ \\
\hline \multirow{2}{*}{$\begin{array}{l}\text { Triptone Soya } \\
\text { Broth }\end{array}$} & $20^{\circ} \mathrm{C}$ & 0 & 0 & $14(70)$ & $6(30)$ & $0.22 \pm 0.04^{\mathrm{c}}$ \\
\cline { 2 - 6 } & $37^{\circ} \mathrm{C}$ & 0 & $4(20)$ & $16(80)$ & 0 & $0.36 \pm 0.08^{\mathrm{b}}$ \\
\hline
\end{tabular}

OD - optical density; SD - standard deviation. - Non biofilm producer: OD $\leq 0.207$; weak biofilm producer: $0.207<\mathrm{OD} \leq 0.414$; moderate biofilm producer: $0.414<\mathrm{OD} \leq 0.828$; strong biofilm producer: $\mathrm{OD}>0.828$

The results showed that the effect of the broth was statistically significant $(\mathrm{P}<0.05)$, while the effect of temperature showed no statistical significance $(\mathrm{P}=0.13)$. An interaction effect of the broth and temperature was observed $(\mathrm{P}<0.05)$. 
Scanning electron microscopy. The selected isolate of $S$. Tennessee produced a characteristic biofilm structure on the surface of the stainless steel coupon after incubation in LB broth at $20{ }^{\circ} \mathrm{C}$ (Fig. 2. a, b). Micrographs 2. a and 2. b show the distinct threedimensional biofilm structure of microcolonies embedded in an extracellular substance (matrix). Cultivation of the isolate in TSB at $20{ }^{\circ} \mathrm{C}$ did not result in biofilm formation on the coupon surface, but only individual bacterial cells were observed (Fig. 2. c, d).
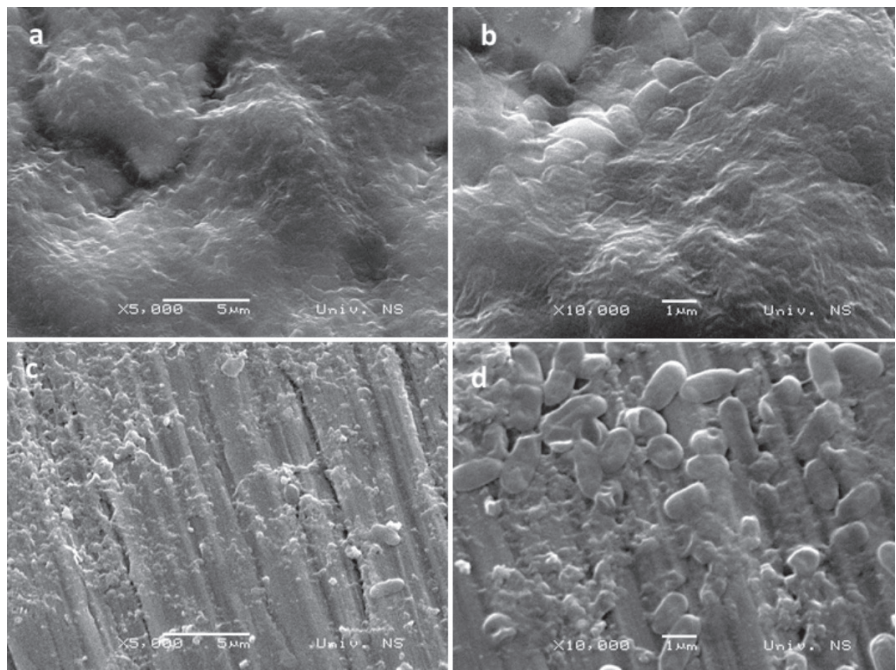

Fig. 2. Scanning electron microscopy: $S$. Tennessee biofilm on a stainless steel surface, incubation at $20{ }^{\circ} \mathrm{C}$ in $\mathrm{LB}(\mathrm{a}, \mathrm{b})$; individual cells of the same strain, incubation at $20{ }^{\circ} \mathrm{C}$ in $\mathrm{TSB}(\mathrm{c}, \mathrm{d})$

\section{Discussion}

Throughout the two-year research period, $S$. Tennessee was the most frequently isolated serovar from animal feed. The starting point for this research was the role of the biofilm-forming ability of $S$. Tennessee strains in their wide distribution in the environment (plant surfaces), and consequently their frequent isolation from animal feed of plant origin. The ability for biofilm formation was examined in 20 strains $S$. Tennessee isolated from feed for cattle, pigs, poultry and soybean meal, originating from different feed factories.

Biofilm production was quantitatively tested on a polystyrene surface using microtiter plates. The isolates were cultivated into two media: nutrient-limited Luria Bertani broth (LB) and a nutrient-rich medium Tryptone Soya Broth (TSB) at two incubation temperatures: $20^{\circ} \mathrm{C}$ and $37^{\circ} \mathrm{C}$. According to the results obtained from the microplate test (Table 1.), all isolates of $S$. Tennessee created a biofilm when cultivated in LB at $20^{\circ} \mathrm{C}$. 
Under these conditions, 14 isolates were categorized as moderate, and six as weak biofilm producers. Isolate cultivation at the same incubation temperature $\left(20^{\circ} \mathrm{C}\right)$ in TSB revealed 14 weak biofilm producers, whereas six isolates did not produce a biofilm. The obtained results correspond to the reports of other researchers, indicating that a nutrient-poor medium enhances the biofilm formation of Salmonella spp. (HOOD and ZOTTOLA, 1997; STEPANOVIĆ et al., 2004). This can be explained by the fact that the maximum expression of the major transcriptional regulator $\mathrm{CsgD}$ (curli subunit gene $\mathrm{D}$, also described as $\mathrm{AgfD}$ ) under aerobic conditions occurs in a nutrient-limited medium (GERSTEL and RÖMLING, 2001; STEPANOVIĆ et al., 2004). CsgD triggers the synthesis of two key biofilm matrix components, i.e., a protein component (curli fimbriae) and a polysaccharide (cellulose) (RÖMLING, 2005; JONAS et al., 2007). CsgD directly activates aggregative fimbriae genes $(a g f)$ encoding for the synthesis of curli fimbriae, and indirectly the genes $b c s A$, $b c s B, b c s Z$ and $b c s C$ (bacterial cellulose synthesis), encoding the synthesis of cellulose (RÖMLING, 2005; JONAS et al., 2007). The stimulative effect of nutrient limitation on biofilm formation of $S$. Tennessee on a stainless steel surface was confirmed using scanning electron microscopy. The selected isolate $S$.Tennessee produced a biofilm at the incubation temperature of $20^{\circ} \mathrm{C}$ when cultivated in LB (Fig. $2 \mathrm{a}, \mathrm{b}$ ), yet not in TSB (Fig. $2 \mathrm{c}, \mathrm{d}$ ). The pronounced ability of biofilm formation on a stainless steel surface at low temperatures with nutrient deficiency might be of paramount importance for the persistence of serovar Tennessee on the equipment and contact surfaces in feed factories, where stainless steel is the preferred material because of its hardness and resistance to chemical treatment (disinfection).

The higher incubation temperature $\left(37{ }^{\circ} \mathrm{C}\right)$ also negatively affected biofilm production by isolates of $S$. Tennessee in the microplate biofilm assay. The negative effect of higher temperature on biofilm production may be explained by the lack of synthesis of curli fimbriae, which in Salmonella commonly takes place at temperatures below $30{ }^{\circ} \mathrm{C}$ (SOLANO et al., 2002; GERSTEL and RÖMLING, 2003). Curli fimbriae are extracellular protein polymers of vital importance for initial adhesion onto biotic and abiotic surfaces, and early cell aggregation (WHITE and SURETTE, 2006; JONAS et al., 2007). In the microplate biofilm assay, the isolates of $S$. Tennessee did not form a visible biofilm on the bottom of the polystyrene plate wells; however, they formed a clearly visible pellicle in the liquid-air interface. The formation of a pellicle is characteristic of Salmonella species, signifying their preference for aerobic growth conditions (LAMAS et al., 2016). An important role in pellicle formation is attributed to BapA protein (biofilm associated protein $\mathrm{A}$ ), a large secreted protein, which is loosely associated with the cell surface (LATASA et al., 2005; JONAS et al., 2007). Curli, cellulose and the cell surface protein BapA are the key components of the Salmonella biofilm matrix (JONAS et al., 2007; VESTBY et al., 2009). 


\section{Milanov et al.: Biofilm forming ability of Salmonella ser. Tennessee isolated from feed}

Nutrient starvation and low temperatures stimulate the expression of genes responsible for biofilm formation and thus the production of Salmonella rdar morphotype when grown on Congo Red agar (CEVALLOS-CEVALLOS et al., 2012). In our research, all isolates of $S$. Tennessee formed rdar morphotype colonies on CRA when incubated at $20{ }^{\circ} \mathrm{C}$, that is, they expressed curli fimbriae and cellulose (Fig. 1. a, b). The role of the rdar morphotype in the persistence of Salmonella in various environments has been established in a number of studies (CEVALLOS-CEVALLOS et al., 2012). Lower temperatures and nutrient deficiency, which trigger the mechanisms for biofilm formation, suggest that the multicellular behavior of Salmonellae is their basic surviving strategy in the environment, outside the host. The active invasion of plants by Salmonella involves both biofilm matrix components (curli fimbriae and cellulose). Salmonellae biofilms on plant surfaces have been identified using in situ visualization techniques (PATEL and SHARMA, 2010; LAPIDOT and YARON, 2009). Having no specific defense mechanisms to prevent colonization and invasion, plants do not recognize salmonellas as pathogens. In that respect, biofilm formation is a successful survival strategy of Salmonella in the environmental niche, which is an important segment of their life cycle until a new infection outbreak.

Genetic differences between individual Salmonella serotypes most likely contribute to their ability to survive in stress conditions. Thus, the specific adaptability of the serovar Tennessee to environmental conditions may be related to the presence of specific genes. Long-lasting desiccation, osmotic stress and low $\mathrm{pH}$ promote survival through the activation of a stress response regulator (rpoS). Prolonged feed storage under dry conditions may result in an increase in the virulence of $S$. Tennessee, since the expression of virulence genes, such as hilA, invA and $\operatorname{sip} C$, is partially regulated by the stress response regulator rpoS (AVILES et al., 2013). In feed factory facilities, the maintenance of a dry environment is one of the basic measures for the control of pathogenic bacteria; however, it has little or no effect on Salmonellae, which are highly adaptable to dry conditions (MØRETRØ et al., 2009). The ability of $S$. Tennessee strains to persist in the feed mill environment was confirmed by molecular methods. Thus, the application of pulsed field gel electrophoresis (PFGE) confirmed the clonal identity of $S$. Tennessee strains isolated in the 2003-2005 period and those isolated in the 2008-2009 period (HÄGGBLOM, 2009). Furthermore, finished animal feed products are usually characterized by low moisture content, yet this proved ineffective in the elimination of salmonellas. It has been confirmed that Salmonella can survive even more than 16 months in poultry feed stored at $25^{\circ} \mathrm{C}$ (PAPADOPOULOU et al., 2009). A range of research has confirmed that the survival of $S$. Tennessee is not affected by low water activity storage (CDC 1993; AVILES et al., 2013).

The available literature data revealed that $S$. Tennessee is of no particular importance to the epidemiology of human salmonellosis. According to the reports by the National 
Salmonella Surveillance System from 1995 to 2009, S. Tennessee was identified as the etiological agent in $0.1 \%$ of all salmonellosis cases (CDC 2011). In the Republic of Serbia, $S$. Tennessee was not reported as the causative agent of human salmonellosis in the 1999-2010 period (WHO 2015). However, this serovar was frequently detected in animal feed, which is a gate for microbial entrance into the food chain. Non-Typhi serotypes of Salmonella enterica from feeds induce colonization or infection in foodproducing animals, hence posing an indirect risk for human health (CRUMP et al., 2002; ALVAREZ et al., 2003; PAPADOPOULOU et al., 2009; VESTBY et al., 2009). Apparently, serovars present in animal feed differ from those commonly identified in humans, which is most probably because different strains survive in different environments (ALVAREZ et al., 2003). Moreover, the control of feed contamination needs substantial improvement since Salmonella isolates are not typed to the serovar level and the causal relationship between the contamination of products of animal origin and a disease outbreak in humans is extremely difficult to establish (CRUMP et al., 2002).

\section{Conclusion}

Salmonella Tennessee is one of the most widely distributed serovars of NTS in animal feed and its components of plant origin. The serovar is characterized by its great ability for biofilm formation on biotic and abiotic surfaces, which contributes to its wide distribution in nature and persistence in feed and the feed factory environment. Lower temperatures, nutrient deficiency and low water activity are the main environmental factors which trigger biofilm formation in $S$. Tennessee. Most probably, farm animals and humans are not natural hosts for the serovar Tennessee, since it has rarely been identified as a causative agent of human salmonellosis.

\section{Acknowledgements}

This work was supported by a grant from the Ministry of Education, Science and Technological Development of the Republic of Serbia (Project number TR 31071).

\section{References}

ALVAREZ, J., S. PORWOLLIK, I. LACONCHA, V. GISAKIS, A. B. VIVANCO, I. GONZALEZ, S. ECHENAGUSIA, N. ZABALA, F. BLACKMER, M. McCLELLAND, A. REMENTERIA, J. GARAIZAR (2003): Detection of a Salmonella enterica serovar California strain spreading in Spanish feed mills and genetic characterization with DNA microarrays. Appl. Environ. Microbiol. 69, 7531-7534.

AVILES, B., C. KLOTZ, J. EIFERT, R. WILLIAMS, M. PONDER (2013): Biofilms promote survival and virulence of Salmonella enterica sv. Tennessee during prolonged dry storage and after passage through an in vitro digestion system. Int. J. Food Microbiol. 162, 252-259. 
D. Milanov et al.: Biofilm forming ability of Salmonella ser. Tennessee isolated from feed

CDC, CENTERS FOR DISEASE CONTROL AND PREVENTION (2011): National Salmonella Surveillance Annual Data Summary, 2009. Atlanta, Georgia: US Department of Health and Human Services, CDC, 2011.

CDC, CENTERS FOR DISEASE CONTROL AND PREVENTION (1993): Salmonella serotype Tennessee in powdered milk products and infant formula - Canada and United States, 1993. MMWR 1993; 42, 516-517.

CEVAllos-CeVAllos, J. M., G. GU, M. D. DANYLUK, A. H. C. Van BRUGGEN (2012): Adhesion and splash dispersal of Salmonella enterica Typhimurium on tomato leaflets: Effects of rdar morphotype and trichome density. Int. J. Food Microbiol. 160, 58-64.

CHRISTENSEN, J. P., D. J. BROWN, M. MADSEN, J. E. OLSEN, M. BISGAARD (1997): Hatchery-borne Salmonella enterica serovar Tennessee infections in broilers. Avian Pathol. 26, 155-168.

CRUMP, J.A., P. M. GRIFFIN, F. J. ANGULO (2002): Bacterial contamination of animal feed and its relationship to human illness. Clin. Infect. Dis. 35, 859-865.

GERSTEL, U., U. RÖMLING (2001): Oxigen tension and nutrient starvation are major signals that regulate agfD promoter activity and expression of the multicellular morphotype in Salmonella Typhimurium. Environ. Microbiol. 3, 638-648.

GERSTEL, U., U. RÖMLING (2003): The $\operatorname{csg} D$ promoter, a control unit for biofilm formation in Salmonella typhimurium. Res. Microbiol. 154, 659-667.

HÄGGBLOM, P. (2009): The feed borne outbreak of Salmonella Tennessee in Finland in the spring of 2009. National Veterinary Institute, Uppsala, Sweden. Accessed Mar. 2010. www.mmm. fi/attachments $/ \mathrm{mmm} / \mathrm{tiedotteet} / 5 \mathrm{mlkunEwY} /$ The_feed_borne_outbreak_of_Salmonella_ Tennessee_in_Finland_in_the_spring_of_2009.pdf.

HOOD, S. K., E. A. ZOTTOLA (1997): Adherence to stainless steel by foodborne microorganisms during growth in model food systems. Int. J. Food Microbiol. 37, 145-153.

ISO, International Organization for Standardization, Geneva (2008): EN ISO 6579:2008: Microbiology of food and animal feeding stuffs - Horizontal method for the detection of Salmonella spp. ISO standard 6579: 2008. ISO, Geneva, Switzerland.

JONAS, K., H. TOMENIUS, A. KADER, S. NORMARK, U. RÖMLING, L. M. BELOVA, Ö. MELEFORS (2007): Roles of curli, cellulose and BapA in Salmonella biofilm morphology studied by atomic force microscopy. BMC Microbiol. 7:70. Available from http://www. biomedcentral.com/1471-2180/7/70.

KROUPITSKI, Y., D. GOLBERG, E. BELAUSOV, R. PINTO, D. SWARTZBERG, D. GRANOT, S. SELA (2009): Intenalization of Salmonella enterica in leaves is induced by light and involves chemotaxis and penetration through open stomata. Appl. Environ. Microbiol. 75, 6076-6086.

LAMAS, A., J. M. MIRANDA, B. VÁZQUEZ, A. CEPEDA, C. M. FRANCO (2016): Biofilm formation, phenotypic production of cellulose and gene expression in Salmonella enterica decrease under anaerobic conditions. Int. J. Food Microbiol. 238, 63-67. 
D. Milanov et al.: Biofilm forming ability of Salmonella ser. Tennessee isolated from feed

LAPIDOT, A., S. YARON (2009): Transfer of Salmonella enterica serovar Typhimurium from contaminated irrigation water to parsley is dependent on curli and cellulose, the biofilm matrix components. J. Food Prot. 72, 618-623.

LATASA, C., A. ROUX, A. TOLEDO-ARANA, J.M. GHIGO, C. GAMAZO, J. R. PENADES, I. LASA (2005): BapA, a large secreted protein required for biofilm formation and host colonization of Salmonella enterica serovar Enteritidis. Mol. Microbiol. 58, 1322-1339.

MØRETRØ, T., L. K. VESTBY, L. L. NESSE, S. E. STORHEIM, K. KOTLARZ, S. LANGSRUD (2009): Evaluation of efficacy of disinfectants against Salmonella from the feed industry. J. Appl. Microbiol. 106, 1005-1012.

NESSE, L. L., K. NORDBY, E. HEIR, B. BERGSJOE, T. VARDUND, H. NYGAARD, G. HOLSTAD (2003): Molecular analyses of Salmonella enterica isolates from fish feed factories and fish feed ingredients. Appl. Environ. Microbiol. 69, 1075-1081.

PAPADOPOUlOU, C., J. J. CARRIQUE-MAS, R. H. DAVIES, A. R. SAYERS (2009): Retrospective analysis of Salmonella isolates recovered from animal feed in Great Britain. Vet. Rec. 165, 681-688.

PATEL, J., M. SHARMA (2010): Differences in attachment of Salmonella enterica serovars to cabbage and lettuce leaves. Int. J. Food Microbiol. 139, 41-47.

RÖMLING, U. (2005): Characterization of the rdar morphotype, a multicellular behavior in Enterobacteriaceae. Cell. Mol. Life Sci. 62, 1234-1246.

SOLANO, C., B. GARCIA, J. VALLE, C. BERASAIN, J. M. GHIGO, C. GAMAZO, I. LASA (2002): Genetic analysis of Salmonella enteritidis biofilm formation: critical role of cellulose. Mol. Microbiol. 43, 793-808.

STEPANOVIĆ, S., I. ĆIRKOVIĆ, V. MIJAC, M. ŠVABIĆ-VLAHOVIĆ (2003): Influence of the incubation temperature, atmosphere and dynamic conditions on biofilm formation by Salmonella spp. Food Microbiol. 20, 339-343.

STEPANOVIĆ, S., I. ĆIRKOVIĆ, L. RANIN, M. ŠVABIĆ-VLAHOVIĆ (2004): Biofilm formation by Salmonella spp. and Listeria monocytogenes on plastic surface. Lett. Appl. Microbiol. 38, 428-432.

VESTBY, L. K., T. MØRETRØ, S. LANGSRUD, E. HEIR, L. L. NESSE (2009): Biofilm forming abilities of Salmonella are correlated with persistence in fish meal- and feed factories. BMC Vet. Res. 5:20. Available from www.biomedcentral.com/1746-6148/5/20

WHITE, A. P., M. G. SURETTE (2006): Comparative genetics of the rdar morphotype in Salmonella. J. Bacteriol. 188, 8395-8406.

WHO, WORLD HEALTH ORGANIZATION (2015): Global Foodborne Infections Network, year data viewed. Top 15 Salmonella Serotype list, Top 15 list from a Country, Serbia, Institute of Public Health of Serbia. Available from http://thor.dfvf.dk/pls/portal/GSS.COUNTRY DATA SET REP.show

WHO, WORLD HEALTH ORGANIZATION (2013): Salmonella (non-typhoidal) Fact sheet $\mathrm{N}^{\circ} 139$, August 2013. Available from www.who.int/mediacentre/factsheets /fs139/en/ 
D. Milanov et al.: Biofilm forming ability of Salmonella ser. Tennessee isolated from feed

Received: 9 June 2016

Accepted: 23 May 2017

\section{MILANOV, D., B. PRUNIĆ, D. LJUBOJEVIĆ: Istraživanje sposobnosti tvorbe biofilma u sojeva Salmonella enterica serovar Tennessee izdvojenih iz hrane za životinje. Vet. arhiv 87, 691-702, 2017.}

\section{SAŽETAK}

Salmonella enterica subsp. enterica serovar Tennessee bio je najčešće ustanovljen u hrani za životinje biljnog podrijetla u dvogodišnjem razdoblju istraživanja (2012 - 2013.) na području Autonomne pokrajine Vojvodine. Istražena je sposobnost proizvodnje biofilma kod 20 izolata serovara Tennessee, s polaznom pretpostavkom da sojevi toga serovara imaju dobru sposobnost tvorbe biofilma i da ta osobina značajno doprinosi njihovoj rasprostranjenosti u prirodnom okruženju (biljna materija), a posljedično i u hrani za životinje. Biofilm je bio proizveden na površinama od polistirena (test na mikrotitracijskim pliticama) i nehrđajućeg čelika (skenirajuća elektronska mikroskopija) uzgojem u Luria Bertani bujonu (LB) i tripton soja bujonu (TSB). Ekspresija glavnih komponenti matriksa biofilma salmonela (fimbrije i celuloza) istražena je uzgojem izolata na agaru s kongo crvenilom. Svi izolati serovara Tennessee tvorili su biofilm na površini polistirena u testu na mikrotitracijskim pliticama, uzgojem u LB na temperaturi inkubacije od $20^{\circ} \mathrm{C}$. Skenirajućom elektronskom mikroskopijom, na površini nehrđajućeg čelika ustanovljena je proizvodnja biofilma uzgojem u LB, ali ne i u TSB. Svi izolati tvorili su kovrčave fimbrije i celulozu te oblikovali kolonije karakterističnog rdar morfotipa na agaru s kongo crvenilom. Serovar Tennessee nije specifično adaptiran na ljude i životinje i prema epidemiološkim podatcima nema osobito značenje u pojavi hranom prenosivih infekcija. Međutim, on posjeduje izraženu sposobnost adherencije na površinu biljaka, sposobnost produkcije biofilma i otpornost na isušivanje, što vjerojatno doprinosi njegovom čestom nalazu u hrani za životinje s niskim sadržajem vlage.

Ključne riječi: Salmonella Tennessee, biofilm, hrana za životinje 